\title{
Tamás Nótári Law and Society in Lex Baiuvariorum
}

(Schenk Verlag, Passau, 2014, pp 288, ISBN 978-3944850-25-2, Euro 39.90)

In this monograph, Tamás Nótári investigates certain legal and socio-historical aspects of the lex Baiuvariorum, but also gives ample space to a philological analysis of its Medieval Latin.

The first chapter (Historical and social background - Bavaria in the eighth century), examines Bavaria's history and society during the first half of the eighth century. Specifically, it deals with Bavaria's home and foreign affairs and church organisation, and certain issues pertaining to the structure of society, namely, the evolution of the Bavarian nobility and the status of freemen and slaves. It furthermore analyses the end of the independent Bavarian Dukedom, focusing on the dethronement of Tasilo III, the last duke of the Agilolfing dynasty, and the legal background of the dethronement. ${ }^{1}$

The second chapter deals with the history of the compilation of the lex Baiuvariorum; and more specifically discusses such issues as dating it; possible connections between the content of the narrative in the Prologus and the process of drawing up the code of laws; the significance of the first two titles of the code in terms of dating it; and problems relating to editing the lex Baiuvariorum. In the course of this discussion, with regard to the final version Nótári accepts Peter Landau's hypothesis that monks who compiled it must have belonged to the St Emmeram

1 On the philological aspects of the sources analysed in this chapter see, also, T Nótári Bavarian Historiography in Early-Medieval Salzburg (Passau, 2010) (hereafter Nótári Bavarian Historiography); T Nótári "An Early-Medieval 'Show Trial' - Tasilo IIIs Dethronement" in L Beck Varela, P Gutiérrez Vega \& A Spinosa (eds) Crossing Legal Cultures (München, 2009) 141158 (hereafter Nótári 'Show Trial').

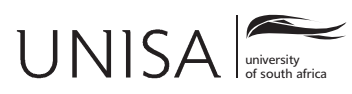


monastery located at the duke's seat in Regensburg; and that to date the compilation between 737 and 743 is supported by the ecclesiastical influence apparent in the lex Baiuvariorum, far exceeding that of Bavarian folk laws. At the same time, the author emphasises that it is almost impossible to draw any conclusions that are appropriate in every respect on the authenticity of the Prologus; in other words, its content can hardly enable us to date the code of laws accurately. He does, however, agree with Heinrich Brunner's hypothesis that certain parts of the lex Alamannorum and the first two titles of the lex Baiuvariorum may be traced back to a lost Merovingian statute. The first two titles of the lex Baiuvariorum, on the one hand, constitute an integral whole in terms of their structure and language and the manuscripts left to us, whilst on the other hand these titles and the provisions of the lex Alamannorum on the Church and the ruler clearly overlap. It is, therefore, possible that at least these titles were integrated as a single unit from the very start; since the editors of the code could hardly, every time the code was revised, go back to the statutes that were the sources of the first two titles, namely the Codex Euricianus and the lex Alamannorum.

In the third chapter (Public and private law in the lex Baiuvariorum) the author deals with issues of criminal law. In early medieval German laws a dogmatic distinction between criminal and private law was not apparent. The author starts by discussing issues of criminal law in an attempt to extract the "general provisions" (allgemeiner Teil) of the criminal law of the Bavarian lex. He defines the "special provisions" (besonderer Teil) and systematises the sanctions of the code. The section on the private law of the lex Baiuvariorum examines procedural law, family law, the law of property and the law of obligations - more specifically, issues concerning sale such as required formalities, validity and warranties. It also touches briefly on other contracts and discusses the law of inheritance as reflected in the sources. ${ }^{2}$ In the next chapter the private and criminal-law position of slaves is analysed, with reference to issues of terminology, slaves as the subject of legal transactions, transactions entered into by slaves and the nature of peculium, damaging of servi alieni and the problems of sanctioning crimes committed by slaves.

The author then states that among German Volksrechte it is the lex Baiuvariorum that contains the greatest number of contractual provisions - and the most flexible ones, specifically with a view to the requirements of practice. Their prime aim indicated expressis verbis in the code is to ensure the continued validity of concluded contracts and the security of transactions. These Bavarian statutory provisions are mainly derived from Visigothic patterns; however, lawmakers did not copy them slavishly, but modified them in accordance with their own experience. With regard to provisions on slaves, it should be made clear that the lex Baiuvariorum (in spite of its significant contribution on this subject), as compared to other German folk

2 Cf T Nótári "Criminal law in Lex Baiuvariorum" (2013) 2/1 Acta Universitatis Sapientiae Legal Studies at 67-90; Nótári Bavarian Historiography (n 1) passim; Nótári 'Show Trial' (n 1) at 141-158. 
laws, did not make any significant attempt to improve the position and acknowledge the humanity of persons deprived of their freedom. Thus it seems that the words mancipium, servus and ancilla may also be translated by the word slave, instead of the usual terms servant and maidservant that are further removed from the legal content. ${ }^{3}$

The fourth chapter analysed by Tamás Nótári deals with the language, sources and impact of the lex Baiuvariorum. The first section, which discusses the German linguistic elements of the code, focuses on the general characteristics of the German phrases of the lex Baiuvariorum; the problems of the ex asse Bavarian phrases of the text of the code; further (possible) Bavarian phrases; the scope of Bavarian personal names; expressions corresponding to the lex Alamannorum; terms that may be presumed to be of Bavarian origin, and other German phrases. An attempt is then made to draw conclusions from the foregoing discussion. Most of the German phrases of the lex Baiuvariorum appear in the text as ancient, extremely characteristic compounds: firstly, they explain or supplement the Latin text; secondly, they convey the appropriate Latin terms, with a German technical term usually constituting an independent part of the sentence; and thirdly, they appear as independent phrases with or without a Latin explanation. Several of the German phrases of non-Bavarian origin were borrowed from the lex Alamannorum. Certain words are also found in the lex Salica. However, it should be pointed out that several Salian Frankish terms, absent from the lex Salica, may be found in the lex Baiuvariorum. They may derive from later laws, capitularia. In addition, numerous words demonstrate the linguistic relation between the Edictus Rothari and the lex Baiuvariorum, whilst some words overlap only partially. Thus the question remains whether the scales should tilt towards borrowing or towards overlapping because of common German roots.

The analysis of the use of sources by the compilers of the lex Baiuvariorum touches on possible secular and ecclesiastical sources of the code, the Visigothic influence and the relationship to Alemannian laws, which make it possible to draw several conclusions. In analysing the sources of the lex Baiuvariorum, Nótári points out that the editors of the lex Baiuvariorum drew mainly from the Codex Euricianus and specifically the titles De commendatis et commodatis, De ventitionibus, De furto and De terminis ruptis. Except in the chapter on contract law, it cannot be determined to what extent the compilers of the lex Baiuvariorum made use of the Codex Euricianus. The editors of the lex Baiuvariorum made a conscious selection from the Visigothic prefiguration, and instead of slavishly copying, adapted parts to the circumstances of Bavarian life. However, they modified them with regard to several topics; in accordance, for example, with the status of the persons concerned. In respect of other sources, especially the lex Alamannorum, Nótári probably presumes that the two codes did not impact on each other, but rather that a common

3 See, also, T Nótári "Personal status and social structure in Early Medieval Bavaria" (2009) 50 Acta Juridica Hungarica at 85-110. 
antecedent (presumably from the Merovingian period) was used by the editors of both codes. The canon law collections, which cannot be determined specifically, were also used as sources by the compilers of the lex Baiuvariorum according to their own needs; in other words, they tried to introduce passages from them into the fabric of the Bavarian code as organic elements.

In the next chapter, Nótári makes a comparative analysis of the factual elements of grave robbery, and considers to what extent elements of Roman law, canon law and especially German customary law are found in specific codes. In this context, the author also analyses the Gothic, Burgundian, Langobardic, Frankish, Alemannian and Bavarian laws. With regard to all these codices Nótári concludes that the formulation of the facts of the robbery or desecration of a grave and the related sanction in the lex Baiuvariorum may be traced clearly to Roman and canon-law roots and that neither the system of sanctions, nor the images related to it imply any genuine connection with ancient German (pagan) thought and religion. ${ }^{4}$

In the last chapter on the history of the influence of the lex Baiuvariorum one circumstance is highlighted, namely the influence of the Bavarian lex on the laws of King Stephen I. The relevant sections analyse the tradition and the surviving texts of King Stephen I and the main characteristics of his legislation; the issues of continuity and discontinuity in the first Hungarian decreta; the ways in which eastern and western sources were used; the main subjects of the regulations of the decreta, and which text demonstrates the influence of the lex Baiuvariorum on the laws of King Stephen I. This analysis shows that where the laws of King Stephen I borrow from the lex Baiuvariorum, the two often overlap. This is to be seen partly in the structure, partly in the preamble, and partly in several particular loci of the law. Regarding particular loci of the law, borrowing seems probable with regard to the topics of Sunday rest and of abduction. Borrowing is certain, however, in respect of arson and high treason; in other words, the treatment of these topics confirms that the author of the first Hungarian laws was familiar with the content of the Bavarian code and made use of it. This makes it highly probable that it was also used in the other cases. ${ }^{5}$

Magdolna Sič

Associate Professor, University of Novi Sad

$4 \quad C f$ T Nótári "The state of facts of robbing a grave in Early Medieval German laws" 2012 (53) Acta Juridica Hungarica at 236-254.

5 See also, T Nótári "Remarks on the Decreta of the first Hungarian King, Stephen I" (2012) 18(2) Fundamina at 108-118. 